\title{
Influence of Mercury Exposure on Oxidative Stress Biomarkers in Longitudinal Muscle of Holothuria forskali
}

\author{
Imen Rabeh ${ }^{1,}$, Khaoula Telahigue ${ }^{1, \text { ", Tarek Hajji }}{ }^{2}$, Chaima Fouzai ${ }^{1}$, Safa Bejaoui ${ }^{1}$, \\ Lassaad Chouba ${ }^{3}$, Mhamed EI Cafsi ${ }^{1}$, Nejla Soudani ${ }^{1}$ \\ ${ }^{1}$ Laboratory of Ecology, Biology and Physiology of Aquatic Organisms, Faculty of Science of Tunis, University of Tunis El Manar, Tunis, \\ Tunisia \\ ${ }^{2}$ Higher Institute of Biotechnology - Sidi Thabet, Biotechpole Sidi Thabet, Univ. Manouba, Ariana, Tunisia \\ ${ }^{3}$ National Institute of Marine Science and Technology (INSTM), La Goulette, Tunis, Tunisia
}

Email address:

rabehimen6@gmail.com (I. Rabeh)

${ }^{*}$ Corresponding author

\section{To cite this article:}

Imen Rabeh, Khaoula Telahigue, Tarek Hajji, Chaima Fouzai, Safa Bejaoui, Lassaad Chouba, Mhamed El Cafsi' Nejla Soudani. Influence of Mercury Exposure on Oxidative Stress Biomarkers in Longitudinal Muscle of Holothuria forskali. International Journal of Ecotoxicology and Ecobiology. Vol. 5, No. 4, 2020, pp. 56-60. doi: 10.11648/j.ijee.20200504.13

Received: November 20, 2020; Accepted: December 9, 2020; Published: December 16, 2020

\begin{abstract}
Mercury ( $\mathrm{Hg}$ ) pollution is featuring as one of the major threat for marine ecosystem, biota and human health. Thereby, the objective of the current study was to evaluate the effect of environmentally relevant concentrations of mercury on oxidative stress, enzymatic and non-enzymatic antioxidant defenses and metallothionein levels in the longitudinal muscle of sea cucumber Holothuria forskali. With this purpose, sea cucumber were exposed to graded concentrations of mercury chloride $\mathrm{HgCl}_{2}\left(40,80\right.$ and $\left.160 \mu \mathrm{g} \mathrm{L}{ }^{-1}\right)$ for $96 \mathrm{~h}$ under controlled conditions. Our findings revealed that $\mathrm{Hg}$ burden in the longitudinal muscle tended to increase with increasing $\mathrm{HgCl}_{2}$ concentrations. The $\mathrm{Hg}$ exposure promoted muscular oxidative stress as evidenced by the increased levels of malondialdehyde (MDA), advanced oxidation protein product (AOPP) and metallothionein (MT) of treated animals compared with controls. Additionally, significant increases in the activities of the enzymatic (glutathione peroxidase (GPx), superoxide dismutase (SOD) and catalase (CAT)) and non-enzymatic (non-protein thiol (NPSH) and glutathione (GSH)) antioxidants were also observed in all treated groups. Overall, this study proved that mercury is able to produce deleterious effects even at the lowest environmentally-realistic concentration in the Holothuria forskali longitudinal muscle which may be considered as a target tissue of mercury accumulation in holothurian.
\end{abstract}

Keywords: Holothuria forskali, Mercuric Chloride $\left(\mathrm{HgCl}_{2}\right)$, Longitudinal Muscle $\mathrm{Hg}$ Burden, Enzymatic and Non-enzymatic Antioxidant

\section{Introduction}

The development of industrial, anthropogenic and agricultural activities conduct to a predominantly degradation of ecosystems exhibiting animals to a vast array of hazardous inorganic and organic contaminates [1]. Aquatic ecosystems are particularly vulnerable to these xenobiotics and act as a sink for several metals [2]. Among metals, mercury is considered as one of the most perilous heavy metals in the marine environment, mainly because it can accumulate in tissues of aquatic animals at concentrations higher than those found in water [3]. Several studies based on aquatic organism models have elucidated that $\mathrm{Hg}$ exerts its toxicity through the induction of oxidative stress particularly in the bioaccumulative tissues by binding to sulfhydryl groups eventually to disrupted enzymatic pathways and metabolism $[4,5]$. The oxidative stress mostly take place when the production of reactive oxygen species (ROS) exceeds the rate of its elimination/decomposition capacity by scavengers, which can lead to lipid peroxidation (LPO) causing cell dysfunction or even cell death [6]. Among aquatic invertebrates, sea cucumbers, extremely vulnerable to the pollution since they are a deposit-feeder ingesting surface sediments [7]. The later is considered as a reservoir for many 
pollutants, especially heavy metal [8]. Furthermore, several authors have reported that sea cucumber depurate these elements relatively heavily suggesting that they could act as integrators of metal contamination in the environment [9]. Physiological responses of some holothurians to heavy metal pollution, were chiefly based on behavioral response, growth, survival and fundamental physiological activities of the animal [10]. Generally, some tissues/organs such as body wall and respiratory tree have received some particular attention to evaluate the impact of noxious stimuli in holothurians due to their respiratory and detoxifying functions; however, little information are available on the longitudinal muscles.

Consequently, the current experiment was designed to gain some more insight of accumulation/toxicity mechanisms of mercury on Holothuria forskali. For this purpose we assessed the effects of $\mathrm{Hg}$ graded dose on disruption of prooxidant/antioxidant balance and metallothionein response in longitudinal muscle of sea cucumber (Holothuria forskali) in interaction with $\mathrm{Hg}$ burden.

\section{Materials and Methods}

\subsection{Animals and Experimental Set-up}

Sea cucumber $H$. forskali used in the study were collected using a hand during scuba diving from Bizerte coasts (North east of Tunisia), a relatively clean sea shore. Samples were transported rapidly to the laboratory in boxes with water from the collection site. To reduce the effect of body size on biochemical responses to mercury, $H$. forskali individuals with similar length were selected $(20.25 \pm 2.75 \mathrm{~cm}$ of the body length). Once in the laboratory, the specimens were held in tanks filled with aerated seawater (closed-system). Samples were maintained separately in these conditions for 3 days in a room with controlled photoperiod (12h light: $12 \mathrm{~h}$ dark) and temperature $\left(18 \pm 1^{\circ} \mathrm{C}\right)$. Acclimated animals were randomly divided into 4 groups of 12 specimens each ( in triplicate design) in order to ensure the reproducibility of the results. As we have proceeded in our previously published researches [11, 12], animals were exposed to a series of mercury chloride

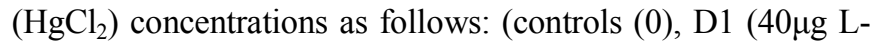

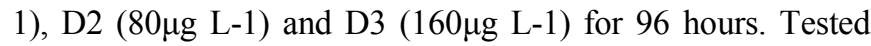
doses were chosen based on studies that investigated the effects of the acute exposure of marine invertebrates to mercury, using similar concentrations $[13,14]$ (Bhamre et al., 2010; Oliveira et al., 2015). The lowest concentration (40 $\mathrm{mg} / \mathrm{L}$ ) was in the range of concentrations that can be found in some heavily contaminated water bodies near industrialized areas $[15,16]$, while the highest tested concentrations (60 and $80 \mathrm{mg} / \mathrm{L}$ ), were selected to guarantee an observable effects of $\mathrm{Hg}$ and to elucidate the responsiveness of sea cucumber to worst-case-scenario of mercury contamination. In order to avoid prandial effects, animals were not fed during acclimation neither during the trial. To ensure water quality, $50 \%$ of the water was replaced every $24 \mathrm{~h}$ and concentrations of mercuric chloride were re-established.

\subsection{Tissue Samples}

At the end of experiments, nine animals were dissected and muscle was carefully dissected and immediately frozen into liquid nitrogen and then stored at $-80^{\circ} \mathrm{C}$ until the biochemical assays were carried out. Some portions were used for mercury quantification and other samples were rinsed, homogenised in phosphate buffer $(0.1 \mathrm{M}, \mathrm{pH}=7.4)$ and centrifuged at $10,000 \times \mathrm{g}$ for $20 \mathrm{~min}$ at $4^{\circ} \mathrm{C}$.

\subsection{Determination of Total Mercury}

All samples were freeze dried, ground in a mortar and homogenized. Total mercury $(\mathrm{Hg})$ was analysed at National Marine Institute of Sciences and Technologies with Direct Mercury Analyser (DMA 80$)\left(\mathrm{LD}=0.4 \mathrm{ngg}^{-1}\right)$. The principle of the DMA analyser is based on thermal decomposition, amalgamation and atomic spectrometry detection. The quality assurance of the analytical results was controlled with the use of the certified reference materials (CRM, Nist 2976). QA/QC was achieved by using Replicated, method blanks and standard reference material. Replicated $(n=2)$ measures of CMR and reagent blanks, were used to assess accuracy (estimated as 95\%). The analytical precision was generally better than $6 \%$. All metal concentrations are reported in $\mu \mathrm{g} / \mathrm{g}$ of dry weight of sample.

\subsection{Protein Quantification}

Muscle protein contents was determined according to the method of Lowry et al. [17] using bovine serum albumin as standard. The supernatant absorbance was determined at 540 $\mathrm{nm}$ using a spectrophotometer All biochemical biomarker responses were normalised to total protein concentration.

\subsection{Malondialdehyde (MDA) Assay}

Lipid peroxidation was estimated by measuring thiobarbituric acid (TBA)-reactive substances and was expressed in terms of malondialdehyde (MDA) content in muscle according to the method of Draper and Hadley [18]. Absorbance was measured at $532 \mathrm{~nm}$ using a spectrophotometer. The MDA values were calculated using 1,1,3,3-tetra-ethoxypropane as the standard and was given as nmoles of malondialdehyde per milligram of protein.

\subsection{Advanced Oxidation Protein Products (AOPP)}

The advanced oxidation protein product (AOPP) levels were estimated according to the method of Kayali et al. [19]. The absorbance of the reaction mixture was measured at 340 $\mathrm{nm}$ and the results were expressed as micromoles per milligram of protein.

\subsection{Determination of Non-enzymatic Antioxidant Levels}

Non Protein Thiols (NPSH) were determined according to the method of Ellman [20]. Absorbance of colorimetric reaction was measured at $412 \mathrm{~nm}$. Results were expressed as micromoles per gram tissue.

Reduced glutathione (GSH) content in H.forskali muscle 
tissues was measured according to the method of Ellman [20] modified by Jollow et al. [21]. The method is based on the reductive cleavage of 5,5'-dithiobis(2-nitrobenzoic acid) (DTNB) by a sulfhydryl (-SH) group to yield a yellow colour. Briefly, a mixture of tissue homogenates in phosphate buffer and sulfosalicylic acid (4\%) was centrifuged at $1600 \times \mathrm{g}$ for $15 \mathrm{~min}$. A volume of the obtained supernatant was taken and added to Ellman's reagent. The absorbance was measured at $412 \mathrm{~nm}$ after $10 \mathrm{~min}$. Results were expressed as micrograms per gram of protein.

\subsection{Determination of Enzymatic Antioxidant Activities}

Glutathione peroxidase (GPx) activity was estimated with the Flohe and Gunzler [22] method. The enzyme activity was measured spectrophotometrically at $412 \mathrm{~nm}$ and was expressed as nanomoles of glutathione (GSH) oxidised per minute per milligram of protein.

Superoxide dismutase (SOD) activity was estimated at 560 $\mathrm{nm}$ according to Beauchamp and Fridovich [23]. Units of SOD activity were expressed as the amount of enzyme required to inhibit the reduction of NBT by $50 \%$. Results were expressed as units of SOD per milligram of protein.

Catalase (CAT) activity was assayed as described by Aebi [24] and the values were expressed as micromoles of $\mathrm{H}_{2} \mathrm{O}_{2}$ consumed per minute per milligram of protein.

\subsection{Metallothionein (MTs) Content}

(MT) content was estimated spectrophotometrically using a MT assay proposed by Viarengo et al. [25] and modified by
Petrovic et al. [26]. Absorbances were red at $412 \mathrm{~nm}$ and metallothionein levels were expressed as micromoles of GSH per gram of tissue.

\subsection{Statistical Analysis}

Mercuric chloride effects on biochemical variables were analyzed one way ANOVA of variance (ANOVA) followed by the Tukey's test in order to compare results between doses. Results were expressed as mean $\pm \mathrm{SD}$ and differences were considered significant at $\mathrm{p}<0.05$. Firstly, the data for each variable was checked for normality and homogeneity of variance by Kolmogorov-Smirnov and Levene's tests, respectively. Raw values were arcsine-transformed or $\log 10$ transformed (if necessary) to meet the requirements for normal distribution and homogeneity of the variances. Student unpaired t-test was also used when comparison between two groups was required. The $\mathrm{R}$ software version 2.15.2 (R Development Core Team 2017) was used for all statistical tests. [27].

\section{Results}

Total mercury concentrations of all analyzed samples of sea cucumber are summarized in Table 1. Results revealed that after $96 \mathrm{~h}$ of exposure, mercury bioaccumulation in muscle increased significantly in dose dependent manner. Substantial accumulation with a burden of $6.1528 \mu \mathrm{g} \mathrm{g}^{-1}$ tissue wet weight was recorded at D3.

Table 1. Total mean mercury concentrations ( $\mu \mathrm{g} \mathrm{g}^{-1} \mathrm{dw}$ )in Holothuria forskali muscle of controls and $\mathrm{Hg} \mathrm{Cl}_{2}$ treated groups $\left(\mathrm{D1}\left(40 \mu \mathrm{g} L^{-1}\right), \mathrm{D2}\left(80 \mu \mathrm{g} \mathrm{L}^{-1}\right)\right.$ and D3 $\left.\left(160 \mu g L^{-1}\right)\right)$ for 4 days.

\begin{tabular}{lllll}
\hline & Controls & (D1) & (D2) & (D3) \\
\hline $\mathrm{Hg}\left(\mu \mathrm{g} \mathrm{g}^{-1} \mathrm{dw}\right)$ & $0.2088 \pm 0.03$ & $0.6075 \pm 0.078^{* * *}$ & $1.3012 \pm 0.015^{* * *}$ & $6.1528 \pm 0.092^{* * *+\$}$ \\
\hline
\end{tabular}

Data are expressed as mean $\pm \mathrm{SD}(\mathrm{n}=9) .{ }^{* * *} p<0.001$ : D1, D2 and D3 groups $v s$. control group; ${ }^{+} p<0.001$ : D2 and D3 groups $v s . \mathrm{D} 1$ group; ${ }^{\$} p<0.001$ : D3 group vs. D2 group.

Our results revealed a significant increase in the lipid peroxidation, as confirmed by the enhanced malondialdehyde level in a dose dependent manner $(+27,+37$ and $+68 \%$, respectively) in all treated groups when compared to controls (Table 2). We also recorded that the level of AOPP was increased by +58 and $+184 \%$ in D2 and D3 treatments respectively, while it remained unchanged at D1when compared to control.

Effects of mercury on GSH and NPSH levels in the $H$. forskali muscle were summarized in the table 2. A significant increase in GSH (by 19, 39, and $88 \%$, respectively) and NPSH (by 18, 25, and 293\%, respectively) levels was observed in muscle of $H$. forskali exposed to a graded doses when compared to the control group (Table 2).

Table 2. MDA, AOPP, NPSH, GSH, levels in the muscle of control and $\mathrm{HgCl}_{2}$-treated Holothuria forskali $\left(D 1\left(40 \mu g L^{-1}\right), D 2\left(80 \mu g L^{-1}\right)\right.$ and D3 $\left.\left(160 \mu \mathrm{g} L^{-1}\right)\right)$ for 4 days.

\begin{tabular}{|c|c|c|c|c|}
\hline Treatments \& parameters & Controls & D1 & D2 & D3 \\
\hline $\mathrm{MDA}^{\alpha}$ & $29.81 \pm 3.97$ & $37.84 \pm 4.42^{*}$ & $40.78 \pm 3.13^{* *+}$ & $50.02 \pm 5.54^{* * *++\$}$ \\
\hline $\mathrm{AOPP}^{\beta}$ & $0.19 \pm 0.05$ & $0.20 \pm 0.04$ & $0.30 \pm 0.06^{* * *+}$ & $0.54 \pm 0.08^{* * *++\$ \$}$ \\
\hline $\mathrm{NPSH}^{\lambda}$ & $0.16 \pm 0.04$ & $0.19 \pm 0.02^{*}$ & $0.20 \pm 0.03^{* *}$ & $0.63 \pm 0.08^{* * *++\$ \$}$ \\
\hline $\mathrm{GSH}^{\gamma}$ & $4.12 \pm 0.72$ & $4.91 \pm 0.42^{* *}$ & $5.73 \pm 0.65^{* * *+}$ & $7.57 \pm 0.85^{* * *++\$ \$}$ \\
\hline
\end{tabular}

${ }^{\alpha} \mathrm{MDA}=\mathrm{nmol} / \mathrm{mg}$ protein; ${ }^{\beta} \mathrm{AOPP}=\mu \mathrm{mol} / \mathrm{mg}$ protein; ${ }^{\lambda} \mathrm{NPSH}=\mu \mathrm{mol} / \mathrm{g}$ tissue; ${ }^{\gamma} \mathrm{GSH}=\mu \mathrm{g} / \mathrm{g}$ tissue; Data are expressed as mean $\pm \mathrm{SD}(\mathrm{n}=9) .{ }^{*} p<0.05 ; * * p<0.01$; $*_{* *} p<0.001$ : D1, D2 and D3 groups vs. control group; ${ }^{+} p<0.01 ;{ }^{++} p<0.001$ : D2 and D3 groups vs; D1 group. ${ }^{\$} p<0.05$; ${ }^{\$ \$} p<0.001$ : D3 group $v s$. D2 group.

The antioxidant enzyme activities in the muscle are shown in Table 2. The $\mathrm{HgCl}_{2}$ exposure induced significant increases in the muscular SOD $(+14,+26$, and $+48 \%$, respectively) and
GPx activities $(+24,+26$, and $+48 \%$ respectively). As for the CAT activity, an increase in treated animals was apparent only in sea cucumbers exposed to D3 compared with the 
control group (Figure 1).
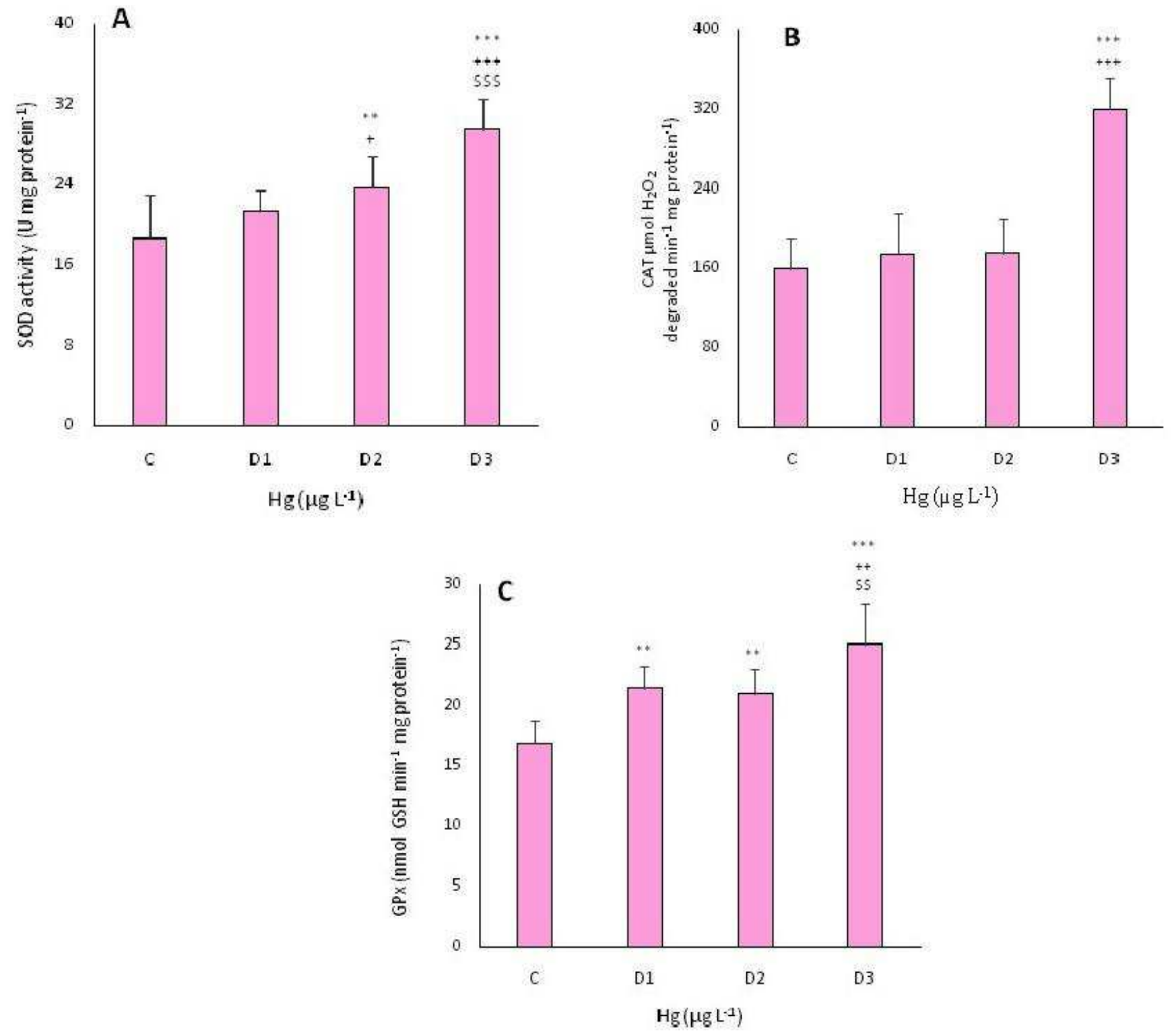

Figure 1. Antioxidant enzymes activities (SOD, CAT and GPx) in the muscle of control and treated Holothuriaforskali with different doses of mercuric chloride: D1 $\left(40 \mu \mathrm{g} \mathrm{L}^{-1}\right), D 2\left(80 \mu \mathrm{g} \mathrm{L} \mathrm{L}^{-1}\right)$ and D3 $\left(160 \mu \mathrm{g} \mathrm{L^{-1 }}\right)$. A: Superoxide dismutase (SOD). B: Catalase (CAT). C: Glutathione peroxidase (GPx). Data were expressed as means $\pm S D(n=9)$. ${ }^{* *} p<0.01$; ${ }^{* * *} p<0.001$ : D1, D2 and D3 groups vs. control group. ${ }^{+} p<0.05 ;{ }^{+++} p<0.001$ : D2 and D3 groups vs. D1 group. ${ }^{\text {ss }} p<0.01 ;{ }^{\text {sss }} p<0.001$ : D3 group vs. D2 group.

As shown in Figure 1, there was an increase by 8 and $10 \%$ respectively of the MT levels in the muscle of D2 and D3 Hg-treated groups when compared to the control. Nevertheless, the lowest dose did not induce any significant change in the MT level when compared to the control.

\section{Discussion}

Some studies have examined mercury burdens in holuturians with a particular interest to the main tissue for xenobiotic detoxification which are commonly challenged against mercury toxicity. Nevertheless, only limited data are available on absorption and accumulation of $\mathrm{Hg}$ on longitudinal muscle of sea cucumber. In our work, the accumulation of $\mathrm{Hg}$ in the $H$. forskali muscle clearly increased with $\mathrm{Hg} \mathrm{Cl} \mathrm{Cl}_{2}$ concentrations, suggesting that this tissue was a target organ for this metal. Throughout our experiment, it is obvious that the muscle may be considered as an accumulative tissue which can be useful in assessing $\mathrm{Hg}$ exposure in echinoderms. It have been documented that exposure of experimental animals to different forms of mercury induce notable imbalances of the oxidative status. In fact, Mercuric ions have a strong affinity to bind directly to protein containing thiol (SH) or selenohydryl groups, which disturb their structure and thereafter damage conclusive function [28]. Additional evidence, has clearly established that an important feature of mercury toxicity is the generation of free radicals that start chain reaction causing the oxidation 
of lipid appointed as lipid peroxidation, protein oxidation and the oxidation of nucleic acid like DNA and ribonucleic acid (RNA) [29]. The results of the experiment clearly revealed, that sea cucumbers exposed to $\mathrm{Hg}$ increased their MDA level, as a lipid peroxidation marker, with the increasing exposure concentrations, agrees well with the observations of several authors $[30,31]$. The peroxidation of lipids, the reaction of oxidative deterioration of membrane polyunsaturated fatty acids, was accompanied by the oxidative damage of proteins as reflected by an increase in the AOPP level in all treated groups. Indeed, AOPP are a family of oxidized, dityrosinecontaining cross-linked protein products generating albumin that cause protein oxidative damage [32]. Mostly, the noxious effects of oxidative distress, are counteracted by using several mechanisms including both nonenzymatic and enzymatic antioxidant defenses. At cellular and molecular level these antioxidant enzymes act in coordination to eliminate free radicals to inactivate ROS and also chelate the metal ions responsible for their generation [33]. Among the endogenous antioxidant enzymes, SOD, CAT, and GPx constitute a cooperatively supportive trio for the neutralization of free radicals [33]. For instance, whilst SOD catalyzes the dismutation of the highly superoxide anion into molecular oxygen $\left(\mathrm{O}_{2}\right)$ and to less $\mathrm{H}_{2} \mathrm{O}$ catalase and GPx do the same for $\mathrm{H}_{2} \mathrm{O}_{2}$ [34]. Our results reveals that the homeostasis of antioxidant defenses was altered, as shown by a significant increase in SOD, CAT, and GPx activities in a dose dependant manner. Our reports are in line with previous studies recorded for other aquatic organisms following exposure to pollutants $[31,35]$. To reach the intended objectives of our experiment, the nonenzymatic antioxidant system in muscle was also considered. It is known that $\mathrm{Hg}$ has a great affinity for sulfhydryl, amine, phosphoryl and carboxyl groups that can result in the alteration of a wide range of enzymes (Shen et al. 2013). The GSH, which is the principal element of NPSH, is an important intracellular antioxidant that can neutralizes reactive oxygen specie and electrophiles [36]. Optimum level of GSH is a substantial criteria to maintain the integrity of cell membranes. Our findings showed a significant increase in the NPSH and GSH levels in the longitudinal muscle of Hg-treated $\mathrm{H}$. forskali which presumably reflects increased request for this antioxidant to contrary the overdone free radical burden. In addition to the antioxidant system, Metallothioneins (MTs), a low molecular cytosolic proteins of high cysteine contents and metal-binding involve in an array of protective stress responses that includes the regulation of homeostasis of essential elements as well as detoxification of xenobiotic metals. In this work, it was possible to observe a significant increase of the MT level in muscle after exposure to $\mathrm{HgCl}_{2}$ confirmed tha $H$. forskali suffers an oxidative stress situation. Since MTs are very rich in the cysteine they can contribute to their high affinity to mercuric ions, by that preserving sulfhydryl groups which are needed for reductive activities, particularly those that are engaged in dismutation of free radicals [37]. Thus, MT, which is considered by several authors as a sensitive indicator of heavy metal contamination in the aquatic environment [38] may particularly be used to assess $\mathrm{Hg}$ exposure in holothurians.

\section{Conclusion}

We demonstrate for the first time a disruption of redox homeostasis in muscle provoked by $\mathrm{Hg}$ exposure in sea cucumber (holothurians). In fact, the analysis of the results obtained in this work yielded the ability of mercury $(\mathrm{HgCl} 2)$ to accumulate in the muscle tissu with the increase of exposure concentration. It can be concluded also that $\mathrm{HgCl}_{2}$ exposure induced a state of oxidative stress in the longitudinal muscle as reaveled by the increased lipid peroxidation, protein oxidation in addition to the disruption of the enzymatic and non-enzymatic antioxidant status. Lastly, our present findings showed that longitudinal muscle constitutes an interesting organ to analyze owing to it major roles in locomotion and contraction movements in response to environmental stimuli and may be used as a target tissue to assess the effect of heavy metal particularity mercury in sea cucumber. Nonetheless, other endpoint tests with holothurians are needed to re-evaluate the concentrations of chemicals allowed in the natural environment where these animals live.

\section{Acknowledgements}

The authors are indebted to the editor and the anonymous reviewers for their acceptance to review this work and their valuable comments and suggestions to improve the quality of the manuscript.

\section{References}

[1] Dudgeon, D. (2010). Prospects for Sustaining Freshwater Biodiversity in the 21 st century: linking ecosystem structure and function. Current Opinion in Environmental Sustainability 2: $422-430$.

[2] Wang, C. Y., Wang, X. L. (2007). Spatial distribution of dissolved $\mathrm{Pb}, \mathrm{Hg}, \mathrm{Cd}, \mathrm{Cu}$ and $\mathrm{As}$ in the Bohai Sea. J. Environ. Sci 19: 1061-1066.

[3] Walters, DM., Rosi-Marshall, E., Kennedy, TA., Cross, WF., Baxter, CV. (2015). Mercury and selenium accumulation in the Colorado River food web, Grand Canyon, USA. Environ Toxicol Chem 34: 2385- 2394. https://doi.org/10.1002/etc.3077.

[4] Farina, M., Rocha, J. B. T., Aschner, M. (2011) Mechanisms of methylmercury-induced neurotoxicity: evidence from experimental studies. Life Sci 89: 555-563.

[5] Kidd, K., Clayden, M. \& Jardine, T. (2012). Bioaccumulation and biomagnification of mercury through food webs. In: LIU, G., CAI, Y. \& O'DRISCOLL, N. (eds.) Environmental chemistry and toxicology of mercury. New Jersey: John Wiley $\&$ Sons, Inc.

[6] Zaman, K., \& Pardini, R. S. (1996). An overview of the relationship between oxidative stress and mercury and arsenic. Toxic Substance Mechanisms 15: 151. 
[7] Jiang, H., Tang, S., Qin, D., Chen, Z., Wang, J., Bai, S., Mou, Z. (2015) Heavy metals in sea cucumber Juveniles from Coastal Areas of Bohai and Yellow Seas, North China. Bull Environ Contam Toxicol 94: 577.

[8] Luoma, S. N. (1990). Processes affecting metal concentrations in estuarine and coastal marine sediments. In: Furness R. W., Rainbow P. S., editors. Heavy Metals in the Marine Environment. Boca Raton, FL USA: CRC Press. pp 51-66.

[9] Warnau, M., Dutrieux, S., Ledent, G., Rodriguez, AM., and Dúbois, P. (2006). Heavy Metals in the Sea Cucumber Holothuria tubulosa (Echinodermata) from the Mediterranean Posidonia oceanica Ecosystem: Body Compartment, Seasonal, Geographical and Bathymetric Variations. Environmental Bioindicators 1: 1-18.

[10] Brown, A., Wright, R., Mevenkamp, Hauton L. C. (2017). A comparative experimental approach to ecotoxicology in shallow-water and deep-sea holothurians suggests similar behavioural responses. Aquat. Toxicol 191: 10-16. doi.org/10.1016/j. aquatox.2017.06.028.

[11] Telahigue, K., Rabeh, I., Bejaoui, S., Hajji, T., Nechi, S., Chelbi, E., El Cafsi, M., Soudani, N. (2018). Mercury disrupts redox status, up-regulates metallothionein and induces genotoxicity in respiratory tree of sea cucumber (Holothuria forskali). Drug Chem Toxicol. 1-11. https://doi.org/10.1080/01480545.2018.1524475.

[12] Rabeh, I., Telahigue, K., Bejaoui, S., Hajji, T., Nechi, S., Chelbi, E., EL Cafsi, M., Soudani, N.

[13] (2018). Effects of mercury graded doses on redox status, metallothionein levels and genotoxicity in the intestine of sea cuccumber Holothuria forskali. Chem. Ecol. https://doi.org/10.1080/02757540.2018.1546292.

[14] Bhamre, P. R., Thorat, S. P., Desai, A. E. and Deoray, B. M. (2010). Evaluation of Acute Toxicity of Mercury, Cadmium and Zinc to a Freshwater Mussel Lamellidensconsobrinus. Our Nature 8: 180-184.

[15] Oliveira, P., Lopes-Lima, M., Machado, J., et al. (2015). Comparative sensitivity of European native (Anodonta anatina) and exotic (Corbicula fluminea) bivalves to mercury. Estuar Coast Shelf Sci 167: 191-198. https://doi.org/10.1016/j.ecss.2015.06.014.

[16] Guilherme, S., Válega, M., Pereira, M., et al. (2008). Antioxidant and biotransformation responses in Liza aurata under environmental mercury exposure relationship with mercury accumulation and implications for public health. Mar Pollut Bull.56: 845-859.

[17] Lowry, O. H., Rosebrough, N. J., Farr, A. L., Randall, R. J. (1951). Protein measurement with the Folin phenol reagent. $J$. Biol. Chem 193 (1): 265-275.

[18] Draper, H. H., Hadley, M. (1990). Malondialdehyde determination as index of lipid peroxidation. Meth. Enzymol $86,421-431$.

[19] Kayali, R., Cakatay, U., Akcay, T., Altug, T. (2006). Effect of alpha-lipoic acid supplementation on markers of protein oxidation in post-mitotic tissues of ageing rat. Cell Biochem. Funct 24 (1): 79-85. https://doi.org/10.1002/cbf.1190.£.

[20] Ellman, G. L. (1959). Tissue Sulfhydryl Groups. Arch. Biochem. Biophys 82 (1): 70-77. doi.org/10.1016/00039861(59)90090-6.
[21] Jollow, D. J., Mitchell, J. R., Zampaglione, N., Gillette, J. R. (1974). Bromobenzene-induced liver necrosis. Protective role of glutathione and evidence for 3, 4-bromobenzene oxide as the hepatotoxic metabolite. Pharmacology 11 (3): 151-169. https://doi.org/10.1159/000136485.

[22] Flohe, L., Gunzler, W. A. (1984). Assays of gluthathione peroxidase. Meth. Enzymol. 105, 114-121.

[23] Beauchamp, C. O., Fridovich, I. (1971). Superoxide dis $\neg$ mutase: improved assays and an assay applicable to acrylamide gels. Anal. Biochem. 44, 276-287. https://doi.org/10.1016/0003-2697(71)90370-8.

[24] Aebi, H. (1984). Catalase in vitro. Methods Enzymol 105: 121-126. doi.org/10.1016/S0076-6879(84)05016-3.

[25] Viarengo, A., Ponzano, E., Dondero, F., Fabbri, R. (1997). A simple spectrophotometric method for metallothionein evaluation in marine organisms: an application to Mediterranean and Antarctic molluscs. Mar. Environ. Res 44: 69-84. https://doi. org/10.1016/S0141-1136(96)001031.

[26] Petrović, S., Ozretić, B., Krajnović-Ozretić, M., Bobinac, D. (2001). Lysosomal membrane stability and metallothioneins in digestive gland of mussels (Mytilus galloprovincialis Lam.) as biomarkers in a field study. Mar. Pollut. Bull. 42 (12): 1373 1378. https:// doi.org/10.1016/S0025-326X(01)00167-9.

[27] R Core Team. (2017) R: a Language and Environment for Statistical Computing.

[28] Bernhoft, R. A. (2012). Mercury Toxicity and Treatment: A Review of the Literature." J Environ Public Health 460508. doi.org/10.1155/2012/460508.

[29] Halliwell, B., Gutteridge, M. C. (1985) The chemistry of oxygen radicals and other oxygen derived species. In: Halliwell, B., Gutteridge, J. M. C. (Eds.), Free Radicals in Biology and Medicine. Clarendon Press, Oxford, pp. 20-66.

[30] Huang W, Cao, L., Ye, Z., Lin, L., Chen, Q., Dou, S. (2012) Tissue-specific bioaccumulation and oxidative stress responses in juvenile Japanese flounder (Paralichthys olivaceus) exposed to mercury. Chin. J. Ocean. Limnol 30 (4): 569. https://doi.org/10. 1007/s00343-012-1210-z.

[31] Wan, P., Wang, R., Wang, C., Qian, J., Hou, J. (2016). Exposure-dose-response relationships of the freshwater bivalve Corbicula fluminea to inorganic mercury in sediments. J. Comput. Theor. Nanosci 13: 5714-5723. https://doi.org/10.1166/jetn.2016.5476.

[32] Cao, W., Xu, J., Zhou, Z. M., Wang, G. B., Hou, F. F, Nie, J. (2013). Advanced oxidation protein products activate intrarenal renin-angiotensin system via a CD36-mediated, redox dependent pathway. Antioxid Redox Signal 18: 1935 .

[33] Howcroft, C. F. et al. (2009). Effects of natural and chemical stressors on Enchytraeus albidus: can oxidative stress parameters be used as fast screening tools for the assessment of different stress impacts in soils?. Environment International 35 (2): 318-324.

[34] McCord, JM., Keele, BB., Fridovich, I. (1976). An enzyme based theory of obligate anaerobiosis. The physiological functions of superoxide dismutase. Proc Natl Acad Sci USA 68: 1024-1027. 
[35] Parolini, M., Magni, S., Castiglioni, S., Binelli, A. (2016). Amphetamine exposure imbalance dantioxidant activity in the bivalve Dreisse napolymorpha causing oxidative and genetic damage. Chemosphere 144: 207-213. http://dx.doi.org/10.1016/j.chemosphere.2015.08.025.

[36] Morris, G., Anderson, G., Dean, O., Berk, M., Galecki, P., Martin-Subero M., Maes, M. (2014). The glutathione system: a new drug target in neuroimmune disorders. Mol. Neurobiol
50 (3): 1059-1084. https://doi.org/10.1007/s12035-014-8705$\mathrm{x}$.

[37] Sura, P., Bronowicka-Adamska, P., Furtak, E., Wróbel, M. (2011). Effect of mercury ions on cysteine metabolism in Xenopus laevis tissues. Comp Biochem Phys C. 154: 180-186 https://doi.org/10.1016/j.cbpc.2011.05.003/.

[38] Rainbow, P. S. (2007). Trace metal bioaccumulation: models, metabolic availability and toxicity. Environ. Int 33: 576e582. 